\title{
予混合火炎の火炎速度に及ぼす固有不安定性の影響*1 The Influence of Intrinsic Instability on the Flame Velocity of Premixed Flames
}

\author{
門脇敏*2 \\ Satoshi KADOWAKI
}

Key Words : Combustion, Simulation, Flame Velocity, Intrinsic Instability

\begin{abstract}
The influence of intrinsic instability on the flame velocity is studied by two- and three-dimensional, unsteady calculations of reactive flows, which are based on the compressible Navier-Stokes equation. We consider three basic types of phenomena which are responsible for the intrinsic instability of premixed flames, i.e., the hydrodynamic, diffusivethermal, and body-force effects. As intrinsic instability becomes stronger, the flame velocity of cellular flames is increased. The increment in flame velocity of three-dimensional flames is about twice that of two-dimensional flames. When the Lewis number is unity, the flame velocity is almost proportional to the flame-surface area. When the Lewis number is lower than unity, on the other hand, the increment in flame velocity is larger than that in flame-surface area. The reason is that the increase in local consumption rate of the unburned gas at a convex flame front with respect to the unburned gas exceeds the decrease at a concave flame front.
\end{abstract}

\section{1.はじめに}

低速で伝播する予混合火炎，例えば水素/空気，炭化水 素/空気予混合火炎では, 火炎自身による不安定性，つま り固有不安定性が生じる.この固有不安定性を引き起こす 要因の中で特に重要なのが, 流体力学的効果, 㹡散・熱的 効果, 外力効果である ${ }^{1 \sim 3)}$. 流体力学的効果は, 火炎面を 通しての気体の熱膨張により生し, 火炎の不安定化に奇与 する4,5).この効果は, 予混合火炎を不安定にする種々の 要因の中で, 最も本質的なものである。なぜなら, 燃焼反 応では発熱を伴うので, 気体の熱膨張が常に生じているか らである。したがって, 流体力学的効果を考慮せずに, 予 混合火炎の不安定性を議論することはできない. 流体力学 的効果と共に重要な要因である拡散・熱的効果は，物質拡 散と熱伝導との選択拡散により生じる ${ }^{6 \sim 8)}$ 。この効果は, 不足成分のルイス数が 1 より小さいとき火炎を不安定化さ せ,ルイス数が 1 より大きいとき火炎を安定化させる. 空 気より軽い（重い）燃料において, 空気 (燃料) 過剩予混 合気でセル状火炎が観察されるが，これは主に㹡散・熱的 効果によるものである．第三の要因である外力効果は，密 度の違う流体が上下に存在するときに生じる，火炎面を通 して気体の密度が大きく変化するので，この効果は地球上 の全ての火炎の不安定性に影響を及涩す，上方へ伝播する 火炎は，外力効果により不安定化され，下方へ伝播する火 炎は安定化される

上で述べた効果により，つまり火炎の固有不安定性によ

\footnotetext{
*1 平成 11 年 12 月 9 日, 第 37 回燃焼シンポジウムにおいて発表.

平成 11 年 12 月 16 日原稿受理

*2 名古屋工業大学機械工学科
}

り，平面火炎上の微小擾乱が発達して，セル状の火炎面が 形成される．火炎面がセル状になることにより，その面積 は増加し, 火炎速度は大きくなる。しかし, 火炎速度の増 加が，火炎面面積の増加のみによるとは限らない。例え ば, 乱流予混合火炎では，不足成分のルイス数が 1 より小 さいとき，火炎速度の增分は火炎面面積の増分より大きく なる ${ }^{12 \sim 14)}$. 同様の現象がセル状火炎においても生じるこ とは, 容易に想像される。

著者はこれまでに，圧縮性ナヴィエ・ストークス方程式 を用いて，二次元非定常反応流れの数值解析を行い，セル 状火炎の火炎速度に及浬す拡散・熱的効果を調べた ${ }^{15)}$ 。そ して，ルイス数が 1 のとき，火炎速度の增分は火炎面面積 の増分と等しくなり,ルイス数が 1 より小さいとき, 前者 の増分は後者の増分より大きくなることを示した。しか し, 前報の数值解析は二次元火炎のみに関するものであ り，三次元火炎は取り报われていない，また，流体力学的 効果や外力効果の影響については，詳細に調べられていな い，そこで本研究では，二次元および三次元予混合火炎の 計算を行い，セル状火炎の火炎速度に及ほす固有不安定性 の影響を調べる。そして，セル状火炎の火炎速度と火炎面 面積との関係を求める.

\section{2. 支配方 程 式}

二次元および三次元の非定常反応流れを考える．化学反 応は一段不可逆の発熱反応であり，反応速度はアレニウス の法則に従うものとする。未燃ガスと既燃ガスは同じ分子 量, 同じルイス数をもち, 理想気体の状態方程式を満たす ものとする.輸送係数と比熱は全領域で一定であるとす

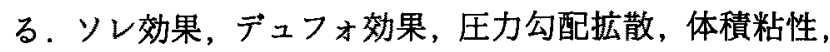


および放射熱流束は無視する，また，外力は主流方向のみ に作用するものとする，固有不安定性の最も本質的な要因 である，流体力学的効果を考虑するため，支配方程式とし て压縮性ナヴィエ・ストークス方程式を用いる。このと き，エネルギー方程式における粘性項と外力項は無視す る、なぜなら、それらの項のエネルギー方程式への寄与 が，本問題では無視できるほど小さいからである，座標は デカルト座標を用い，主流方向を $x$ 方向に，火炎の接線 方向を $y, z$ 方向にとる. 支配方程式は，代表長さ（火炎 の予熱域厚さ＝熱拡散率/燃焼速度)，代表速度（火炎の燃 焼速度)，および末燃ガスの密度を用いて無次元化する．

無次元化された支配方程式は, 保存形で書くと以下のよ うになる。

$$
\frac{\partial \boldsymbol{U}}{\partial t}+\frac{\partial \boldsymbol{F}}{\partial x}+\frac{\partial \boldsymbol{G}}{\partial y}+\frac{\partial \boldsymbol{H}}{\partial z}=\boldsymbol{S}
$$

ベクトル $\boldsymbol{U}, \boldsymbol{F}, \boldsymbol{G}, \boldsymbol{H}, \boldsymbol{S}$ は，以下のように与えられ る。

$$
\begin{aligned}
\boldsymbol{U} & =\left[\begin{array}{l}
\rho \\
\rho u \\
\rho v \\
\rho w \\
e \\
\rho Y
\end{array}\right] \\
\boldsymbol{F} & =\left[\begin{array}{l}
\rho u \\
\rho u^{2}+\frac{p}{\gamma M_{0}{ }^{2}}-\operatorname{Pr}\left(\frac{4}{3} \frac{\partial u}{\partial x}-\frac{2}{3} \frac{\partial v}{\partial y}-\frac{2}{3} \frac{\partial w}{\partial z}\right) \\
\rho u v-\operatorname{Pr}\left(\frac{\partial v}{\partial x}+\frac{\partial u}{\partial y}\right) \\
(e+p)\left(\frac{\partial w}{\partial x}+\frac{\partial u}{\partial z}\right) \\
\gamma-\frac{\gamma}{\gamma-1} \frac{\partial T}{\partial x} \\
\rho Y u-\frac{1}{\operatorname{Le}} \frac{\partial Y}{\partial x}
\end{array}\right]
\end{aligned}
$$

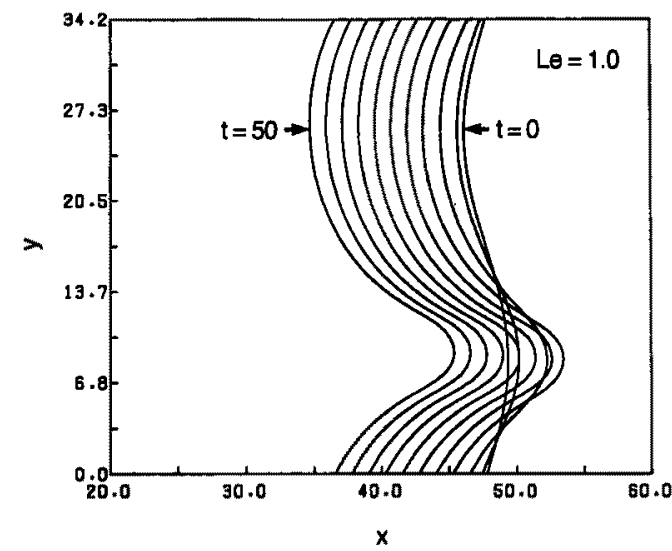

第 1 図 二次元火炎の時間毎の火炎面形状 $\left(L e=1.0, T_{\mathrm{f}}=\right.$ 7.0, $G=0.0, \lambda_{y}=34.2, A_{0}=1.6, t=0,5,10, \cdots, 50$ )

$$
G=\left[\begin{array}{l}
\rho v \\
\rho u v-\operatorname{Pr}\left(\frac{\partial v}{\partial x}+\frac{\partial u}{\partial y}\right) \\
\rho v^{2}+\frac{p}{\gamma M_{0}^{2}}-\operatorname{Pr}\left(\frac{4}{3} \frac{\partial v}{\partial y}-\frac{2}{3} \frac{\partial u}{\partial x}-\frac{2}{3} \frac{\partial w}{\partial z}\right) \\
\rho v w-\operatorname{Pr}\left(\frac{\partial w}{\partial y}+\frac{\partial v}{\partial z}\right) \\
(e+p) v-\frac{\gamma}{\gamma-1} \frac{\partial T}{\partial y} \\
\rho Y v-\frac{1}{L e} \frac{\partial Y}{\partial y}
\end{array}\right]
$$$$
\boldsymbol{H}=\left[\begin{array}{l}
\rho w \\
\rho u w-\operatorname{Pr}\left(\frac{\partial w}{\partial x}+\frac{\partial u}{\partial z}\right) \\
\rho v w-\operatorname{Pr}\left(\frac{\partial w}{\partial y}+\frac{\partial v}{\partial z}\right) \\
\rho w^{2}+\frac{p}{\gamma M_{0}^{2}}-\operatorname{Pr}\left(\frac{4}{3} \frac{\partial w}{\partial z}-\frac{2}{3} \frac{\partial u}{\partial x}-\frac{2}{3} \frac{\partial v}{\partial y}\right) \\
(e+p) w-\frac{\gamma}{\gamma-1} \frac{\partial T}{\partial z} \\
\rho Y w-\frac{1}{L e} \frac{\partial Y}{\partial z}
\end{array}\right]
$$$$
S=\left[\begin{array}{l}
0 \\
G \rho \\
0 \\
0 \\
Q B \rho Y \exp (-E / T) \\
-B \rho Y \exp (-E / T)
\end{array}\right]
$$

ここで, $\rho$ は密度, $u, v, w$ は速度の $x, y, z$ 方向成分， $e$ は単位体積あたりの全エネルギー（内部エネルギー十運 動エネルギー)， $Y$ は末燃ガスの質量分率，力は圧力， $T$ は温度, $\gamma$ は比熱比, $M_{0}$ は燃焼速度のマッ八数, $P r$ は プラントル数, Le はルイス数, $G$ は加速度, $Q$ は発熱 量， $B$ は頻度因子， $E$ は活性化エネルギーである。また， 状態方程式は以下のようになる。

$$
p=\rho T
$$

\section{3. 計 算 手 法}

燃焼速度が $0.83 \mathrm{~m} / \mathrm{s}$ の予混合気を想定する。このと

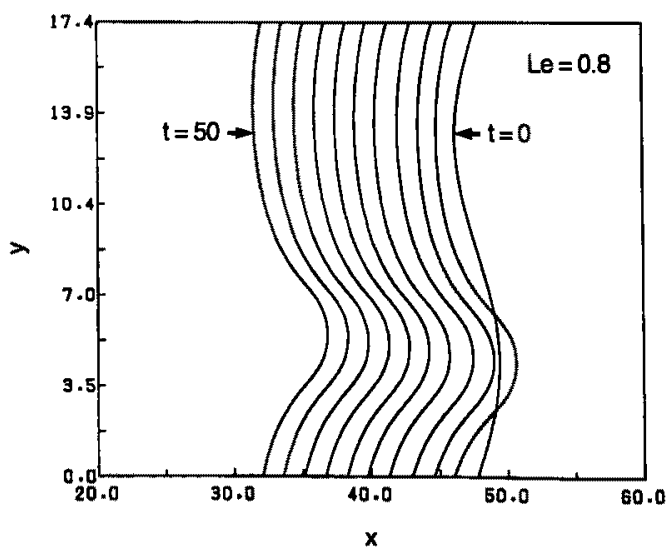

第 2 図 二次元火炎の時間毎の火炎面形状 $\left(L e=0.8, T_{\mathrm{i}}=\right.$ 7.0, $G=0.0, \lambda_{y}=17.4, A_{0}=1.6, t=0,5,10, \cdots, 50$ ) 
き，燃焼速度が気体の音速に較べ充分小さいので $\left(M_{0}=\right.$ $\left.2.1 \times 10^{-3}\right)$, 燃焼速度を変えて計算を行っても, 得られる 結果（無次元化された計算結果）は殆ど変わらない. 支配 方程式中の無次元パラメーターは, $\gamma=1.4, P r=1.0, E$ $=70$ とする. 断熱火炎温度は, $T_{\mathrm{f}}=5.0 \sim 9.0$ とし，ルイ ス数は, $L e=0.5 \sim 1.0$ (ミ1) とする.また, 加速度は, $G=-0.6 \sim 1.5$ とする.なお，火炎が上方（下方）へ伝 播するとき，Gは正(負)である．発熱量は断熱火炎温度 が設定した值になるように定め, 頻度因子は平面火炎の火 炎速度が燃焼速度と等しくなるように定める。

定在平面火炎に $y, z$ 方向に周期的な擾乱を加え，それ を初期值として計算を行う．二次元火炎のときは，正弦波 の擾乱

$$
A_{0} \sin \left(2 \pi y / \lambda_{y}\right)
$$

三次元火炎のときは, 六角形型の擾乱 ${ }^{16)}$

$A_{0}\left[\sin \left(2 \pi y / \lambda_{y}\right) \sin \left(2 \pi z / \lambda_{z}\right)-\cos \left(4 \pi z / \lambda_{z}\right) / 2\right](4)$ を加える.ここで, $A_{0}$ は擾乱の初期振幅， $\lambda_{y}, \lambda_{z}$ は擾乱 の $y, z$ 方向の波長である. 擾乱の波長は特性波長（増幅 率が最大になる波長）と一致させる．なぜなら，セル状火 炎のセルの間隔が特性波長と等しくなるからである ${ }^{17)}$.

火炎の上流側と下流側の境界では, 各々の物理量の $x$ 方向の勾配を 0 とする.上流側の境界の流入速度のみは, 火炎面が大きく前後に移動しないようにするため，燃焼速 度と一致させる。 また， $y, z$ 方向の境界の物理量は, 周 期条件を用いて与える。

計算スキームとしては，時間と空間に対して二次精度で ある陽的マッコーマック法 ${ }^{18)}$ を採用する。計算領域は， $x$ 方向に火炎の予熱域厚さの 160 倍, $y, z$ 方向に援乱の一 波長分とする.そして， $x$ 方向に不等間隔（最小間隔：予 熱域厚さの $1 / 5)$ の格子を, $y, z$ 方向に等間隔の格子を 用いる. 格子数は, 二次元火炎のとき $341 \times 65$, 三次元火 炎のとき $261 \times 31 \times 53$ とする．また，時間ステップは， CFL 条件を満たすように設定する.

\section{4. 結果と考察}

初めに，火炎速度に及ほす拡散・熱的効果の影響を調べ

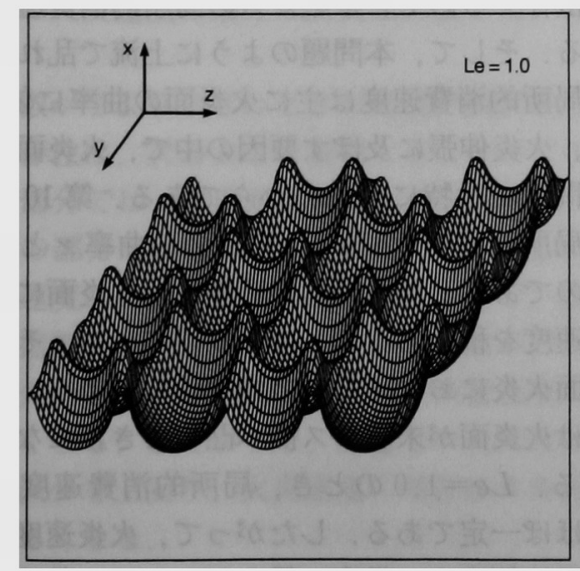

第 3 図

三次元セル状火炎の火炎面形状 $\left(L e=1.0, T_{\mathrm{t}}=7.0\right.$ $G=0.0, \lambda_{y}=39.5, \lambda_{x}=68.4, A_{0}=1.6, t=20$ )
る. $L e=1.0$ と $L e=0.8$ における, 二次元火炎の時間毎 の火炎面形状を示したのが第 1 図と第 2 図である.ここで は，反応速度が最大のところを火炎面と定義している．末 燃ガスは左方から流入し，既燃ガスは右方へ流出する．定 在平面火炎に加えられた摄乱は，計算開始後，火炎の固有 不安定性により，時間と共に増幅する，そして，振幅があ る大きさに達すると, 擾乱は増幅しなくなり, 火炎面はセ ル状になる，その後，火炎はセル形状を保ったまま，上流 側 (末燃ガス側) へ移動する。これは，セル状火炎の火炎 速度が平面火炎のそれより大きいからである．火炎の上流 側への移動速度, つまり火炎速度の増分は, $L e=1.0$ の とき 0.24 であり，Le=0.8のとき 0.30 である。したが って, $L e=1.0$ と $L e=0.8$ における火炎速度は, それぞ れ 1.24 と 1.30 である.

三次元セル状火炎の火炎面形状を示したのが，第 3 図 $(L e=1.0)$ と第 4 図 $(L e=0.8)$ である. 図では， $3 \lambda_{y} \times$ $2 \lambda_{2}$ の領域が描かれている。末燃ガスは下方から流入し， 既燃ガスは上方へ流出する，火炎に加えられた擾乱が増幅 して，セル状火炎が形成される $(t=20)$.これらのセル状 火炎のセルは，第 5 図 $(L e=1.0)$ と第 6 図 $(L e=0.8)$ に示されているように，六角形状に整然と分布している. その後, セル状火炎は上流へ向かって移動する. $L e=1.0$ と $L e=0.8$ における火炎速度の増分は, それそれ 0.59 と 0.71 である．したがって，三次元セル状火炎の火炎速度

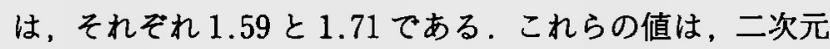
セル状火炎の火炎速度と較べるとかなり大きい。

ルイス数を変えて計算を行い，二次元および三次元セル 状火炎の火炎速度と火炎面面積を求める. 火炎速度 $S_{\mathrm{cr}}$ と 火炎面面積 $L_{\mathrm{ct}}$ に及ほす拡散・熱的効果を示したのが第 7 図である，セル状火炎の火炎面面積は，平面火炎のそれで 標準化してある.ルイス数が小さくなる（ルイス数の逆数 が大きくなる）と共に，火炎速度は増加する，そして，三 次元火炎の火炎速度の増分は，二次元火炎のそれの約 2 倍 である.これは，七ルの分布の仕方の違い，つまり火炎形 状の違いによるものと思われる. 二次元と三次元の両セル 状火炎において，Le=1のとき，無次元火炎速度と標準

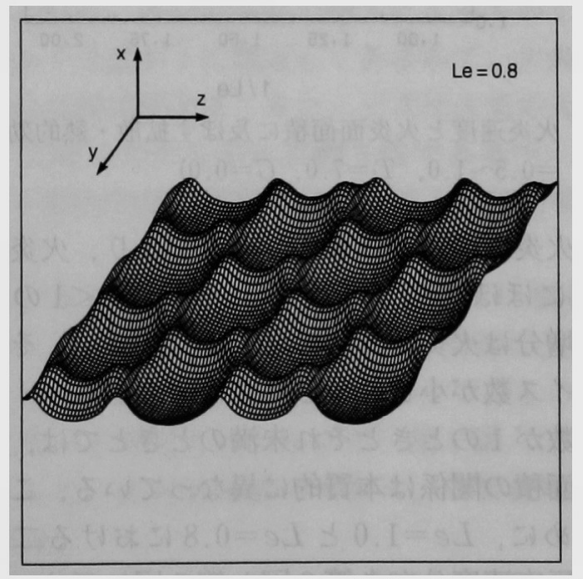

第 4 図 三次元セル状火炎の火炎面形状 $\left(L e=0.8, T_{\mathrm{t}}=7.0\right.$, $G=0.0, \lambda_{y}=20.1, \lambda_{z}=34.9, A_{0}=0.8, t=20$ ) 


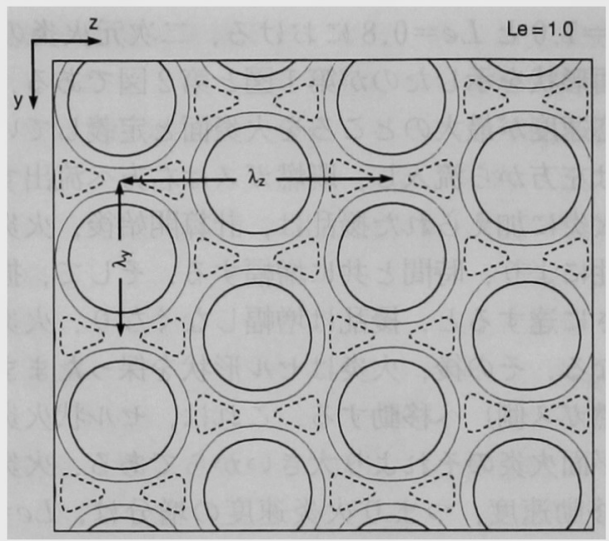

第 5 図 三次元セル状火炎のセルの分布 $\left(L e=1.0, T_{t}=7.0\right.$, $G=0.0$ )

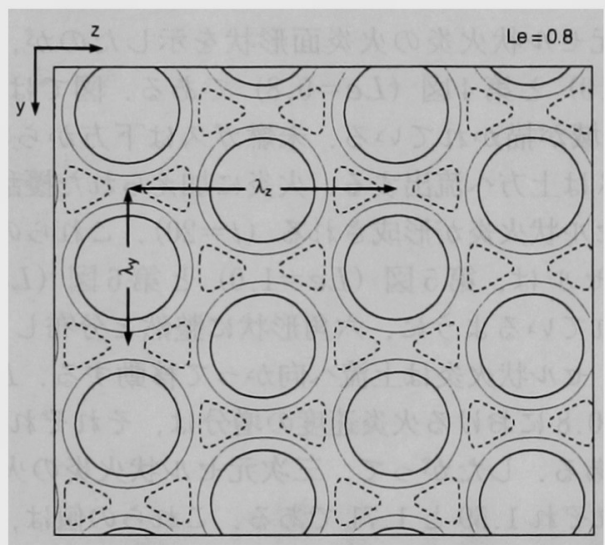

第 6 図 三次元セル状火炎のセルの分布 $\left(L e=0.8, T_{\mathrm{I}}=7.0\right.$, $G=0.0$ )

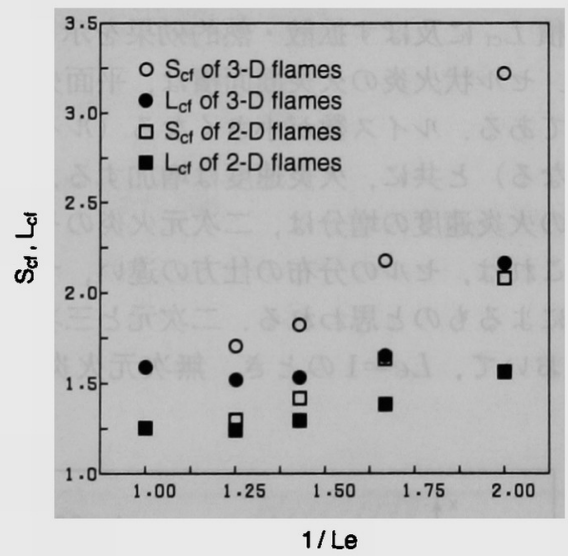

第 7 図 火炎速度と火炎面面積に及ぽす拡散・熱的効果 $(L e$ $=0.5 \sim 1.0, \quad T_{\mathrm{f}}=7.0, \quad G=0.0$ )

化された火炎面面積はほほ等しい，つまり，火炎速度は火 炎面面積にほほ比例している。一方，Le<1のとき，火 炎速度の増分は火炎面面積の増分より大きい. そして，そ の差はルイス数が小さくなると共に増大する．

ルイス数が 1 のときとそれ未満のときとでは, 火炎速度 と火炎面面積の関係は本質的に異なっている．この差異を 調へるために, $L e=1.0$ と $L e=0.8$ における二次元セル 状火炎の反応速度分布を第 8 図と第 9 図に示す. $L e=1.0$ のとき, 火炎面の形状に関係なく，反応速度は火炎面でほ

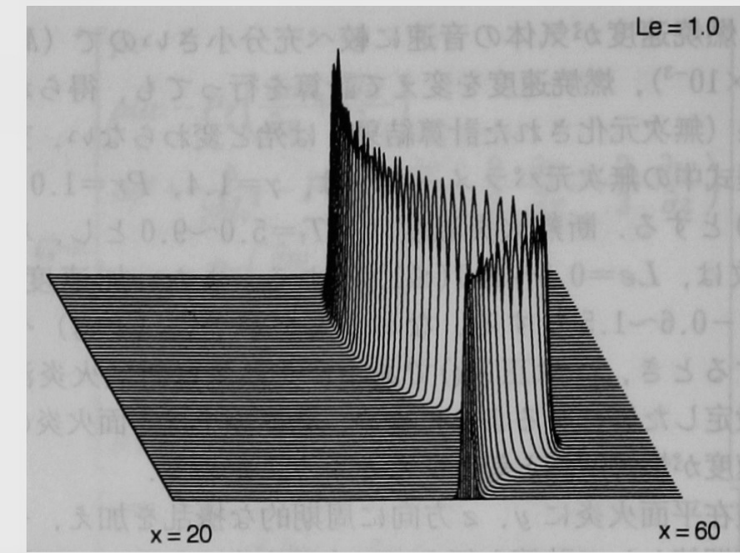

第 8 図 二次元セル状火炎の反応速度分布 $\left(L e=1.0, T_{1}=\right.$ $7.0, G=0.0, t=25$ )

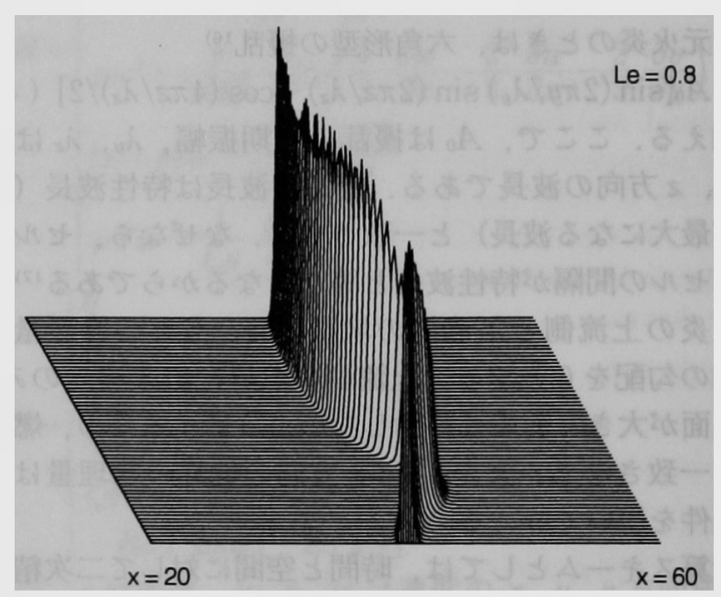

第 9 図 二次元セル状火炎の反応速度分布 $\left(L e=0.8, T_{\mathrm{t}}=\right.$ $7.0, G=0.0, t=25$ )

ほ同じ値をもつ．そして，この值は平面火炎における值と ほほ同じである，一方，Le=0.8のとき，火炎面が未燃 ガス側へ凸の部分で反応速度が大きくなり，凹の部分で小 さくなる。こは，Le<1なので, 物質と熱の選択拡散 により，凸部で火炎の温度が高くなり，凹部でそれが低く なるからである19).ルイス数がさらに小さくなると，局所 的反応速度の火炎面形状への依存性はさらに顕著になる。

ルイス数が 1 より小さいとき，局所的反応速度が火炎面 の形状に依存するので，末燃ガスの局所的消費速度もそれ に依存する．そして，本問題のように上流で乱れが無い場 合には，局所的消費速度は主に火炎面の曲率に依存する， なぜなら，火炎伸張に及ほす要因の中て，火炎面の曲率の 影響が本問題では特に大きいからである。第 10 図は、末 燃ガスの局所的消費速度 $s^{*}$ と火炎面の曲率 $x$ との関係を 示したものである，局所的消費速度は，火炎面に垂直な方 向に反応速度を積分することにより得られる，そして，そ の值は平面火炎におけるそれで標準化してある．また，曲 率の符号は火炎面が末燃ガス側へ凸のとき正になるように 定めてある. $L e=1.0$ のとき，局所的消費速度は曲率に 依存せずほほ一定である。したがって，火炎速度は火炎面 面積にほほ比例する．厳密に言うと，ルイス数が1のとき でも局所的消費速度は火炎面の曲率に依存する2).しか 

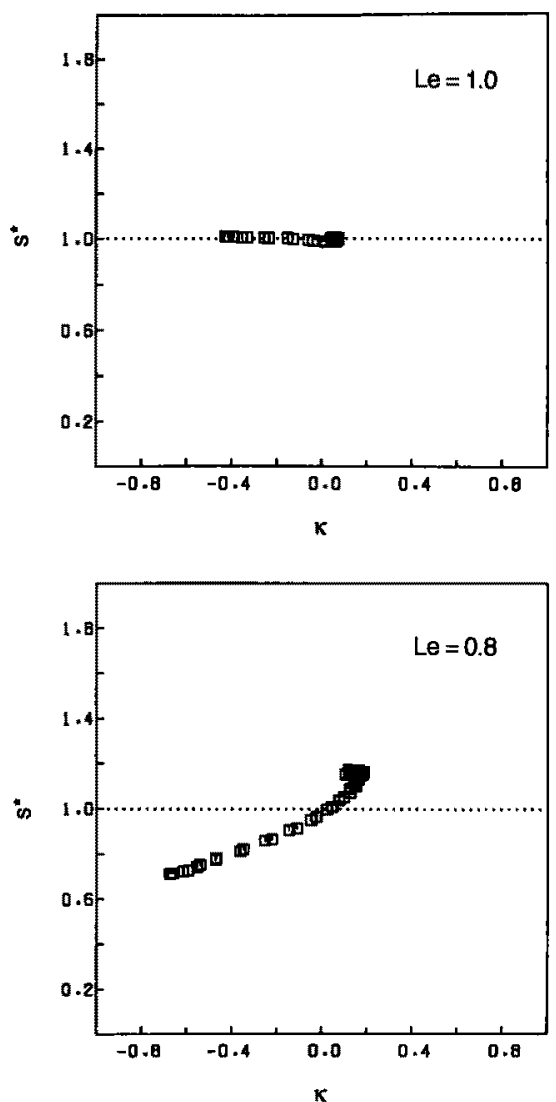

第 10 図末燃ガスの局所的消費速度と火炎面の曲率との関倸 $\left(L e=1.0,0.8, T_{\mathrm{f}}=7.0, G=0.0\right)$

し，セルの間隔が予熱域厚さに較べかなり大きく，曲率が 比較的小さい $(x<1)$ ので, 局所的消費速度の曲率に対 する依存性は，本問題では充分小さい，一方， $L e=0.8$ のとき，曲率が正のとき局所的消費速度は増加し，曲率が 負のとき滅少する．曲率を火炎面に沿って一波長分だけ積 分すると0になるので，局所的消費速度の曲率に対する依 存性が線形であれば，局所的消費速度の増隇は火炎全域で は打ち消し合う。しかし，この場合，その依存性は線形で なく，曲率が大きくなると共に局所的消費速度の增加の割 合は大きくなる．このことは，凸部での消費速度の増加が 凹部での減少を上回ることを示している。したがって，七 ル状火炎の火炎速度の増分は火炎面面積の増分より大きく なる。

ルイス数が 1 より小さいときの局所的消費速度の曲率に 対する依存性は，次のように説明することができる，火炎 面が凸の部分では，温度が上昇し反応速度は大きくなる， 一方，凹の部分では，温度が下降し反応速度は小さくな る. 反応速度はアレニウスの法則に従うので, 温度の上昇 に対して指数的に大きくなる．甲えに，曲率が大きくなる と共に, 火炎の温度が上昇し, 局所的消費速度の増加の割 合は大きくなる。したがって，凸部での消費速度の増加が 凹部での減少を上回り, 火炎速度の増分は火炎面面積の增 分より大きくなる。

次に，火炎速度に及ほす流体力学的効果の影響を調べ る. 第 11 図は，Le=1.0， $T_{\mathrm{f}}=9.0$ における二次元火炎

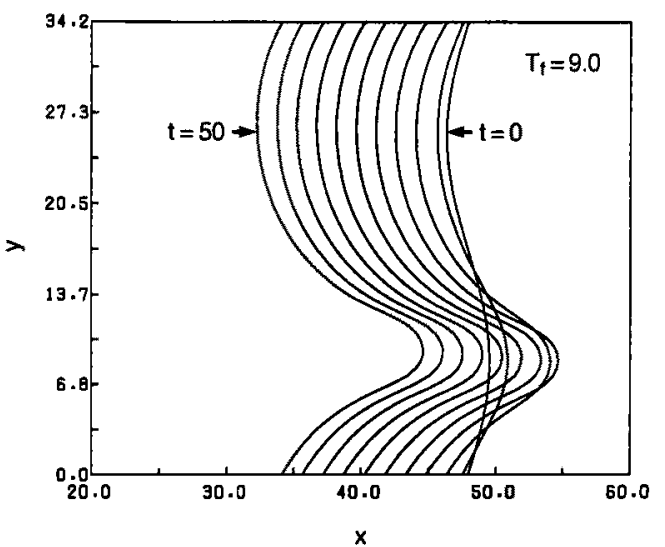

第 11 図 二次元火炎の時間毎の火炎面形状 ( $L e=1.0, T_{\mathrm{f}}=$ $9.0, G=0.0, \lambda_{y}=34.2, A_{0}=1.6, t=0,5,10, \cdots, 50$ )

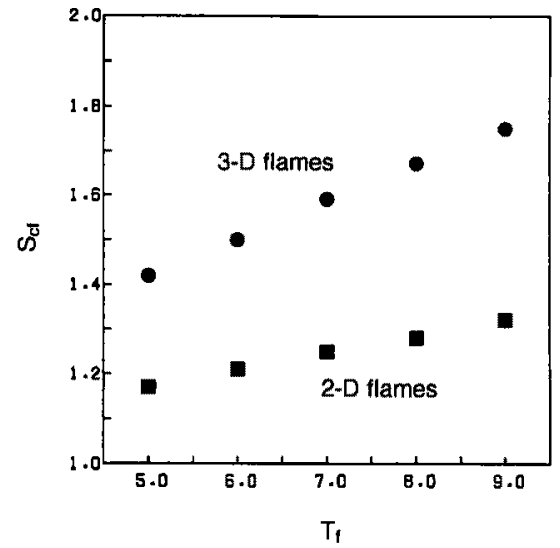

第 12 図火炎速度に及流す流体力学的効果 $\left(L e=1.0, T_{\mathrm{f}}=\right.$ $5.0 \sim 9.0, G=0.0$ )

の時間毎の火炎面形状を示したものである.第 1 図 $\left(T_{\mathrm{f}}\right.$ =7.0) の結果と較べると, 不安定強度が大きいので，セ ルは深く炎炎面は広い。そして，火炎速度も大きい $\left(S_{\mathrm{ct}}\right.$ $=1.31$ ).

断熱火炎温度を変えて計算を行い，二次元招よび三次元 七ル状火炎の火炎速度を求める． $T_{\mathrm{f}}=5.0 \sim 9.0$ における 火炎速度を示したのが第 12 図である．断熱火炎温度が高 くなると共に，火炎面面積は大きくなり，火炎速度も大き くなる，これは，不安定強度の增大によるものである。こ こでは，ルイス数が1に設定してあるので，火炎速度は火 炎面面積にほほ比例する．また，三次元火炎の火炎速度の 増分は，二次元火炎のそれの約 2 倍である ${ }^{20)}$ 。この結果 は，抎散・熱的効果の影響を調べた第 7 図の結果と同様で ある。

最後に，外力効果の影響を調べる，第 13 図は，Le= $1.0, G=0.5$ における二次元火炎の時間毎の火炎面形状 を示したものである。このとき， $G>0$ であるので，外力 効果は火炎の不安定化に作用する。第 1 図 $(G=0)$ の結 果と較べると，火炎面面積は大きく，火炎速度も大きい $\left(S_{\mathrm{cf}}=1.50\right)$.

加速度を変えて計算を行い，二次元および三次元セル状 火炎の火炎速度を求める， $G=-0.6 \sim 1.5$ における火炎 


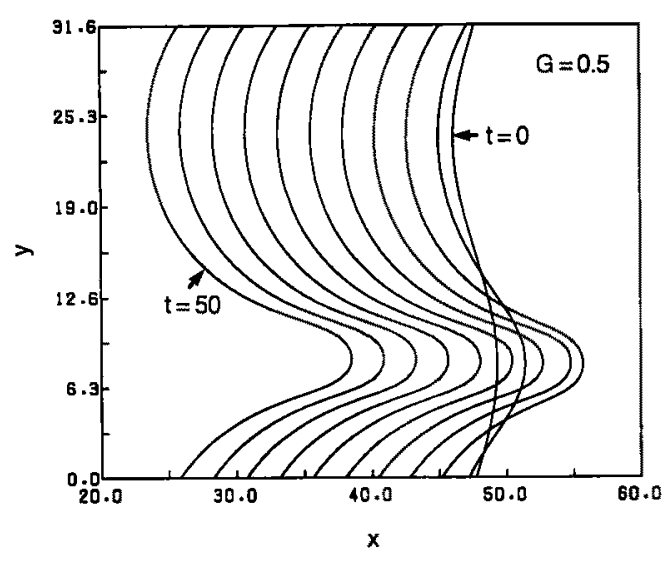

第 13 図 二次元火炏の時間毎の火炎面形状 $\left(L e=1.0, T_{t}=\right.$ 7.0. $G=0.5, \lambda_{y}=31.6, A_{0}=1.6, t=0,5,10, \cdots, 50$ )

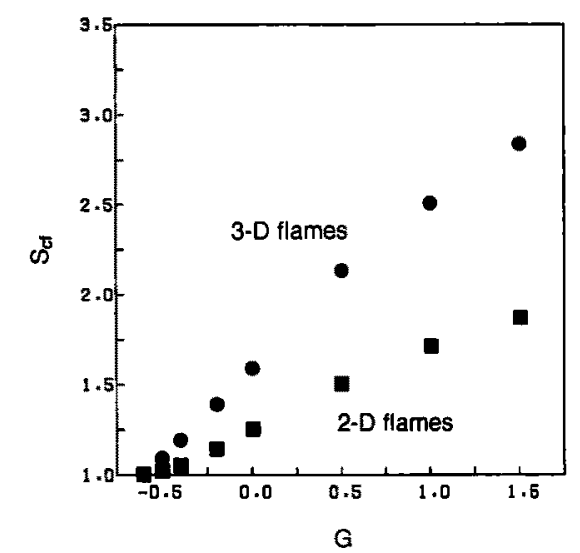

第 14 図 火炎速度に及活す外力効果 $\left(L e=1.0, T_{\mathrm{s}}=7.0, G\right.$ $=-0.6 \sim 1.5$ )

速度を示したのが第 14 図である．G>0のとき，加速度 の増加と共に, つまり不安定強度の増加と共に, 火炎速度 は大きくなる，一方， $G<0$ のとき，火炎速度は $G=0$ の

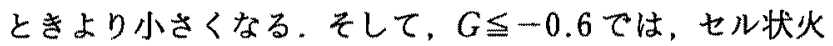
炎は形成されない $\left(S_{\mathrm{cf}}=1\right)$ 。これは, 外力効果が火炎の 安定化に作用し, 流体力学的効果による不安定化を抑える からである。

固有不安定性により，G>-0.6において，七ル状火炎 が形成される，その火炎速度は，加速度が㚆化しても，火 炎面面積にほほ比例する．つまり，外力効果が作用するし ないに関わらず，ルイス数が1であるならば，火炎速度は 火炎面面積にほほ比例する ${ }^{21)}$ 。また, 流体力学的効果と拡 散・熱的効果の影響を調へたた計算（第 7 図と第 12 図）と 同様に，三次元火炎の火炎速度の増分は，二次元火炎のそ れの約 2 倍である。この関係は, 固有不安定性を引き起こ す要因（流体力学的効果, 拡散・熱的効果, 外力効果) $に$ よるのではなく, 二次元火炎と三次元火炎の形状の違いに よるものと思われる。

\section{5. ま と め}

二次元および三次元の非定常反応流れの計算を，圧縮性 ナヴィエ・ストークス方程式を用いて行い, セル状火炎の
火炎速度に及ほす固有不安定性の影響を謂へた．固有不安 定性が強くなると共に, セル状火炎の火炎速度は大きくな る. そして，三次元火炎の火炎速度の增分は二次元火炎の それの約 2 倍である.ルイス数が 1 のとき，火炎速度は火 炎面面積にほほ比例する，一方，ルイス数が1より小さい とき，火炎速度の増分は火炎面面積の増分より大きくな る、これは，凸の火炎面に㧍ける末燃ガスの局所的消費速 度の増加が，凹の火炎面における減少を上回るからである.

\section{参 考 文 献}

1) Sivashinsky, G. I. : Instabilities, Pattern Formation, and Turbulence in Flames, Ann. Rev. Fluid Mech., 15 (1983), pp. 179199.

2) Clavin, P.: Dynamic Behavior of Premixed Flame Fronts in Laminar and Turbulent Flows, Prog. Energy Combust. Sci., 11 (1985), pp. 1-59.

3）Williams, F. A.：燃焼の理論, 柘植俊一監訳, 日刊工業新聞社, 東 京, 1987, pp. 353-385.

4) Darrieus, G.: Unpublished Works Presented at La Technique Moderne, 1938.

5) Landau, L. D.: On the Theory of Slow Combustion, Acta Phys., 19 (1944), pp. 77-85.

6) Barenblatt, G. I., Zeldovich, Y. B. and Istratov, A. G. : On Diffusional-Thermal Stability of a Laminar Flame, J. Appl. Mech. Tech. Phys., 4 (1962), pp. 21-26.

7) Sivashinsky, G. I. : Diffusional-Thermal Theory of Cellular Flames, Combust. Sci. Technol., 15 (1977), pp. 137-145.

8) Joulin, G. and Mitani, T.: Linear Stability Analysis of TwoReactant Flames, Combust. Flame, 40 (1981), pp. 235-246.

9) Markstein, G. H. : Nonsteady Flame Propagation, Pergamon, Oxford, 1964, pp. 15-74.

10) Matkowsky, B. J. and Sivashinsky, G. I. :Acceleration Effects on the Stability of Flame Propagation, SIAM J. Appl. Math., 37 (1979), pp. 669-685.

11) Pelce, P. and Clavin, P.: Influence of Hydrodynamics and Diffusion upon the Stability Limits of Laminar Premixed Flames, J. Fluid Mech., 124 (1982), pp. 219-237.

12) Haworth, D. C. and Poinsot, T. J. : Numerical Simulations of Lewis Number Effects in Turbulent Premixed Flames, J. Fluid Mech., 244 (1992), pp. 405-436.

13）長谷川達也，口田征人，山口举起：予湜合火炎と高强度二次元乱 流との干涉、燃焼の科学と技術, 2 (1994), pp. 77-87.

14）店橋 護, 宮内敏雄, 名田 讓：水菜・空気乱流予混合火炎にお ける乱流と火炎の相互作用，燃焼の科学と技術，6, suppl.（1998）, pp. 13-22.

15）門脇 敏：セル状火炎の燃焼速度に及ほす㹡散・熱的不安定の 影艟, 日本航空宇宙学会誌, 45 (1997), pp. 611-614.

16) Christopherson, D. G. : Note on the Vibration of Membranes, Quarterly J. Math., 11 (1940), pp. 63-65.

17) Kadowaki, S. : Numerical Study on the Instability of Premixed Plane Flames in the Three-Dimensional Field, Int. J. Heat Fluid Flow, 17 (1996), pp. 557-566.

18) MacCormack, R.W. and Baldwin, B.S.: A Numerical Method for Solving the Navier-Stokes Equations with Application to Shock-Boundary Layer Interactions, AIAA Paper, 75-1, 1975.

19) Asato, K., Kawamura, T. and Ban, T.: Effects of Curvature on Extinction of Premixed Flames Stabilized in Stagnation Flow, Proc. 22nd Symp. (Int.) Combust., The Combustion Institute, 1988, pp. 1509-1515.

20) Kadowaki, S.: The Influence of Hydrodynamic Instability on the Structure of Cellular Flames, Phys. Fluids, 11 (1999), pp. 3426-3433

21）門脇 敏：セル状火炎の構造に及ほす外力効果，日本機械学会論 文集 (B 編), 65 (1999)，pp. 3475-3482. 